\title{
COOPERATION BETWEEN COMMUNITY AND LOCAL GOVERNANCE - A COMPARATIVE STUDY OF MUNICIPALITIES OF PRISTINA REGION ${ }^{1}$
}

\author{
Ferdi KAMBERI \\ PhD Candidate \\ University of Pristina 'Hasan Pristina' Faculty of Philosophy - Department of \\ Sociology, Kosovo \\ E-mail: ferdikamberi04@gmail.com
}

\begin{abstract}
$^{2}$
Lately, the development of local government and community has taken new direction, especially in the countries of the Western Balkans, creating a partnership between these two parties. Local government is an important segment that has the legitimacy to organize local public affairs. Whereas community is regarded mainly as a social philosophy pertaining to the domain of communitarianism. More broadly, a community is a unit that includes the social networking, beliefs, values, norms and the social cohesion between its members, who are considered as social capital and are identified as part of the community. In Kosovo, the system of local government is one-tier type, central and local levels of government and municipalities are the basic unit of local government. Whereas the cooperation between the community and local government, although it is regulated by local self-government law, is still a needed practical implementation. It is important for the community to participate in public meetings, which are means used as local decision-making and policymaking mechanisms. The purpose of this study is a comparative analysis between the participation of the communities in the decision-making process in the municipalities of Pristina region (Pristina, Fushe Kosove, Obilic, Drenas and Gracanica) and the use of local decision-making mechanisms. The methodology uses analytical and comparative analysis, focusing on the communities in the Pristina region regarding their participation in public
\end{abstract}

\footnotetext{
${ }^{1}$ A section of research results are part of $\mathrm{PhD}$ thesis with the topic 'Development of the community and local government - a comparative study of municipalities of Pristina'.

2 Correction and proofreading reviewer of article has been made by licensed professional translators Mr. Xhelal Nuhiu \& Muzafer Ramiqi.
} 
meetings. Additionally, the study analyses the empirical research conducted with the communities in the above-mentioned municipalities with a sample of 550 respondents. The results of this research show that the participation of the community in public meetings is low. About $50 \%$ of the study participants indicated that they do not attend public meetings for a number of reasons, such as the sense that their opinions and ideas were disregarded, the distance to the meetings, lack of timely information, and other influential factors.

Keywords: Collaboration, community, local government, case, Pristina region.

\section{Introduction}

The development of the community in recent years has been the focus of study for many scholars, especially for sociologists, because of its role and importance in organizing local life. Community development is considered as the key to building relations between small communities, regardless of ethnic, religious, gender, racial differences. The idea of community development is inspired by cooperation among different entities for a better future. Development is influenced by both the organized communities and the active engagement of citizens within the local government.

A community is often focused on a given geographical area, for example, a local government or a certain city. Therefore, community can also be defined on the basis of common interests, identity, or common characteristics (e.g., a particular cultural or linguistic community). The community, from its development perspective "refers to the citizens or an area, and it doesn't refer to service providers or organizations" (Kamberi, 2019). While, in the recent past, the local government, as a concept, has gone through some significant changes especially through the decentralization process in the South-eastern and Western Balkans. As a result of these changes, a series of reforms were adopted. The reforms have impacted the local community segment, thus creating a partnership between local government and citizens themselves, which did not exist in authoritarianism period. This partnership is one of many principles of the European Charter for Local Government. According to the Preamble of the European Charter: "considering that the right of citizens to participate in the conduct of public affairs is one of the democratic principles that are shared by all member States of the Council of Europe; Considering that it is at the local level that this right can be most directly exercised; convinced that the existence of local authorities with real responsibilities can provide an administration which is both effective and close to the citizen" (Council of Europe, 2013).

Due to this fact, many European countries have started a partnership with its citizens, within the local communities, involving the people in decisionmaking and policy-making processes through local mechanisms, such as public 
meetings. According to Baliqi, "one of most controversial forms of governance and policy analysis is that of the communities, according to which, communities can solve their common issues or problems, by influencing policies and becoming a factor with less and fewer interventions by state authorities" (Baliqi, 2017).

A decision-making process "that allows public participation develops from the very start as a process that perpetuates itself due to the effect of political participation. Participatory political processes have an impact upon the development of the social and political capacities of citizens, and this positively influences the next act of participation. Participation has an integrative effect especially upon those citizens who take part in political activity, and thus makes the acceptance of collective decisions easier" (Kukovič, 2015).

In the Kosovo case, the cooperation between the community and local government is regulated through the European Charter for the Local Government. The charter is incorporated within the Kosovo Constitution and the legal and political institutions in the country through the legislation for local self-government and secondary legislation, although Kosovo is not a signatory of this charter. According to the Law on Local Self-government, the municipality "is the basic unit of local self-government in the Republic of Kosovo, made up of a community of citizens of a specific territory defined by law and shall exercise all powers which are not explicitly reserved for the central institutions" (Law No 03/L-040 on Local Self Government, 2008).

The local government of Kosovo is unitary, a one-level system of decentralization, based on the 2008 Ahtisaari proposal. There are two levels of governance, the central level and the local level also referred to as the municipal level. In Kosovo, there are 38 municipalities, of which 27 are administered by the majority, Albanian community and 10 other municipalities by administered by the Serb community, with only one by the Turkish community. The structure of the local government is composed of two bodies which are elected every four years through democratic free elections: a) the executive body, which includes the municipality mayor and directors, and b) the legislature body, which includes the members of the municipal assembly and the chairman of the assembly. The local administration is composed of civil servants who are the institutional continuity of local self-government. According to the Law on Local Self-government, the municipalities have three kinds of competencies: a) own competencies, b) delegated competences and c) enhanced Municipal Competencies, exclusively dedicated to the municipalities where the majority and do include: Enhanced Competencies in Secondary Health Care, Enhanced Competencies in the University Education, Enhanced Competencies in the Area of Culture and Enhanced Participatory Rights in Selection of the Local Police Station Commanders" (Law No 03/L-040 on Local Self Government, 2008).

The local government reform started in 2004, where the Ministry of Local Government was established as a supervisory institution. This reform was developed at the same time as the decentralization process and had two aspects: 
a) Political aspect - where Serb-majority municipalities were established as an instrument for the integration of the Serb community in the political and public structures of Kosovo.

b) Competency delegation aspect - which has developed simultaneously in line with the political aspect. Perhaps Kosovo is one of the few countries in Europe that delegates competencies exclusively for a certain community, i.e., extended competencies.

The organization and functioning of local communities is regulated by the local government legislation, in particular by the Administrative Instruction (MLGA) No. 02/2019 on the Organization, Functioning and Cooperation of the Municipalities with Villages, Settlements and Urban Quarters. This legislation aims "to regulate the organization, functioning and cooperation of the municipality with the villages, settlements and urban quarters, in the exercise of some activities that are under the responsibility and competence of the municipality" (Administrative Instruction (MLGA) No. 02/2019, 2019). Recently, the Ministry of Local government has drafted an administrative instruction for the Organization, Functioning and Cooperation of the Municipalities with Villages, Settlements and Urban Quarters. Additionally, the ministry has drafted a model regulation as a facilitation mechanism for municipalities so that they can establish local councils, paying greater attention to gender equality, non-majority communities, as well as other actors of civil society. This draft model can be seen as an affirmative form for the involvement of all citizens in the public decision-making processes.

As an institutional mechanism, local communities play an important role in community organization, providing services, and in the development of community life and local government. The main goal of this study is to analyse and compare the cooperation between local communities in the municipalities of the Pristina region, as the largest region in Kosovo, and among local governments. The study uses three main indicators of cooperation: (1) the participation of local communities in public meetings on issues of general social interest in these municipalities; (2) the reasons for (non) participation; and (3) the use of local decision-making mechanisms as an important policymaking process and local decision-making. The study concludes by analysing and comparing the decision-making process of local communities in the municipalities of the Pristina region and the level of use of local decisionmaking mechanisms. This paperwork is the first paperwork of this kind in the field of sociology and political science, and as such does contribute to raising social awareness on participating of the community in public politics by making a colourful democracy and developing active citizenship. Also, does have an impact on local authorities to take more seriously the opinions of the citizens and to create active citizenship. In addition, it does have an impact on local authorities to take more serious ideas and opinions of the community on issues with the public interest and that creates a synergy on interactions between them of the local communities. This contribution does reflect on academics community, civil society, media, science, and broader society. 


\section{Literature review}

The literature review is based on both local and international literature, carefully analysing documents, reports, studies, and research of various local and international civil societies and eminent scholars. Local government is considered one of the primary forms of democracy. It promotes local democracy, which includes stakeholders and is the first step towards achieving a relationship between the local government and the community. According to John Stuart Mill, local government is an integral part of representative democracy. Here, the meaning of local government is twofold: first, the cooperation between the local government and citizens; and secondly, the citizens by participating in policy-making and decision-making. Today, local government is understood as "an autonomous system of government with communities / local communities, established in narrow parts of the state territory. The development of local self-government is one of the conditions of democracy and the rule of law" (Pollozhani et al, 2010). This implies that local government as a concept is "frequently ill-prepared to assume responsibilities for policymaking, resource mobilization and program implementation" (Wilson, 2000).

The Oxford political dictionary defines local government as "a governing institution that exercises authority in a territorially defined area of the country and as important factors for encouraging political education and participation in political life as the basis on which services are organized to meet local needs. It is seen as something rational from an administrative point of view, as it does ensure efficient delivery of public services, where services are needed under the direction of the center" (Iain Mc Lean, 2001). Local government promotes democratic culture and behaviour, transparency in relation to citizens or community and accountability as an essential condition of democracy. As such, it includes various actors which can contribute to the development of local government and improve the lives of citizens.

Local government includes "the public and private sector, local, central and global actors, as well as models related to community self-government" (Baliqi, 2017, p. 283). It is related to 12 principles of good governance which are emphasized by the Council of Europe, such as: (1) Participation, Representation, and Fair Conduct of Elections; (2) Responsiveness; (3) Efficiency and Effectiveness; (4) Openness and Transparency; (5) Rule of Law; (6) Ethical Conduct; (7) Competence and Capacity; (8) Innovation and Openness to Change; (9) Sustainability and Long-Term Orientation; (10) Sound Financial Management; (11) Human Rights, Cultural Diversity and Social Cohesion; and (12) Accountability (ELoGe, 2008).

Community development within the community itself is of particular importance because local communities have a direct impact on many factors, including the empowerment of local groups; the reduction of deviant behaviours; influencing social solidarity that makes them more pro-active within the community and through its development, participation is higher in decision-making processes. Community development, as both a philosophical and social concept has strengthened the relations between individuals who have 
a common goal, a sense of social belonging and identity, values, trust and greater security within the community itself. In this regard, "community development takes on the mantle of developing stronger "communities" of people and the social and psychological ties they share.

Most of the literature defines community development through the component of strengthening the community. Discussions that reflect this aspect focus on community development as an educational process "to enable citizens to address problems by group decision-making" (Phillips \& Pittman, 2009). This process, in the sociological aspect, affects the strengthening of social relations between the communities. It also strengthens the sense of social belonging and identity because the community members see themselves as part of a community that can contribute to the welfare of all the members. Through continuous cooperation, the members can develop their community and as a result, the local government decision-making process becomes easier and more pragmatic.

Oftentimes, the literature generally refers to the community development "as social capital or social capacity, which describes the abilities of residents to organize and mobilize their resources for the accomplishment of consensually defined goals or the resources embedded in social relationships among persons and organizations that facilitate cooperation and collaboration in communities" (Phillips \& Pittman, 2009, p. 6). While other authors such as Putnam, connect the concept of social capital with three main components, "moral obligations and norms, social values (especially trust) and social networks (especially voluntary associations)" (Siisiäinen, 2000).

This definition also correlates with the claims of the French sociologist Emile Durkheim who sees community as a complex and complicated interaction with religion. According to Durkheim community is a connecting mechanism that determines the norms of behavioural interactions and interacts or connects communities together. On the other hand, community participation without such empowerment, cooperation and development does not make sense because the more cooperative the community, the more pro-decision-making it is.

Shery Arnstein's 1969, "Ladders of participation," is a controversial theory about "citizen participation," and "citizen control." She addressed the exploitation of the weak and the poor people by those who have power and control. Arnstein (1969) suggested eight "rungs" of participation, "within which are three main categories or degrees, non-participation, degrees of tokenism and degrees of citizen power". According to her theory, citizen participation in the decision-making process is important because it creates a critical voice to local governance and through participation, citizens can closely monitor the work of elected people at the level of local government. She also highlights eight rungs (ranging from 8 to 1 and not from 1 to 8 ) in three different degrees or categories. The level of active citizenship includes three levels: 8 . Citizen Control, 7. Delegated power, and 6. partnership. The next step is to create an active citizenship image that includes three other rungs: 5. Placation, 4. Consultation, and 3. Informing. And finally, there is also the degree of 
passive citizenship that has two rungs: 2. Collective Therapy, and 1. Manipulation.

Arnstein's theory of a ladder of citizen participation is more of public policy theory, which can also be classified as a theory of political sociology. Based on the ladder of citizen participation theory, the first two levels represent an active citizen who monitors the work of the representatives. Active citizen's decision-making significantly affects the improvement of life of citizens. Meanwhile, referring to the level of passive citizenship "has to do with the nonparticipation of citizens in these processes, with the result that their representatives have the possibility of manipulation and a kind of therapy that she calls collective therapy (which she refers to the passive citizens)" (Kamberi \& Baliqi, 2018).

Arnstein's theoretical framework focuses more on the relationship between community development and local government, namely community participation in decision-making and public meetings. The approach of this scale also shows the modelling and the typology of the active and passive participants. In practice, this often happens because, for various reasons, local communities do not participate at all or only participate partially. They seem to be more passive observers than contributors to the development of policies, which could regulate not only issues of public interest, but also the very life and social welfare of the community itself. Therefore, the community is the first step through which local government can be notified about their problems, challenges or concerns. The active participation of the community, in addition to giving 'spirit' to the community as Etzioni says, also plays an important role in the development of policies which reflect on a better society. This paperwork is the first paperwork of this kind in the field of sociology and political science, and as such does contribute to raising social awareness on participating of the community in public politics by making a colourful democracy and developing active citizenship. Also, does have an impact on local authorities to take more seriously the opinions of the citizens and to create active citizenship. In addition, it does have an impact on local authorities to take more serious ideas and opinions of the community on issues with the public interest and that creates a synergy on interactions between them of the local communities. This contribution does reflect on academics community, civil society, media, science, and broader society.

\section{Data and methodology}

To research community participation in decision-making and policymaking, we conducted a quantitative survey. Part of the survey results presented here are also part of my $\mathrm{PhD}$ thesis. In this survey, 550 respondents were involved $(\mathrm{N}=550)$ in the municipalities of the Pristina region, covering a two-year time span between 2018 and 2019. The questionnaire was conducted directly or face to face and the sample was representative and combined with the simple random one. The sample was distributed as follows: in Pristina, 
27.3\%, Fushë Kosovë 18.2\%, Obiliq 18.2\%, Drenas $18.2 \%$ and Gracanica $18.2 \%$.

The participants' age was over 18 . The representation is organized by age groups, from 18 - 25 years: $16.9 \%$; from 26 - 35 years: $42.9 \%$; from 36 - 45 years: $22.7 \%$; age group 46-55:12.2\%; and 56 years and above: $5.3 \%$. The gender the ratio is: $57 \%$ men and $43 \%$ women. By the level of education: $2.5 \%$ of respondents have no education at all; $11.5 \%$ of them with elementary school $11.5 \% ; 9.5 \%$ of them with secondary education; $50.9 \%$ with college education; $24.4 \%$ of them with master's degree; and $1.3 \%$ with $\mathrm{PhD}$ degree.

By the housing type of living: $60 \%$ of respondents live in a house; and $40 \%$ of the participants live in flats/apartments. By ethnicity: Albanian ethnicity: 70.4\% Serbs; 16\% Turks; 5.3\% Roma, Ashkali and Egyptians; and others: $7.1 \%$.

Table 1. Descriptive analysis of participations in the research.

\begin{tabular}{|l|r|}
\hline Number of respondents & Total 550 \\
\hline Gender & Male 57\% \\
\hline Age group & Female $43 \%$ \\
\hline Education level & $18-25,16.9 \%$ \\
& $26-35,42.9 \%$ \\
& $36-45,22.7 \%$ \\
& $46-55,12.2 \%$ \\
& $55-$ over, 5.3\% \\
\hline Municipalities & Without no school \\
& $2.5 \%$ \\
& Primary school \\
& $11.5 \%$ \\
& Secondary school \\
& $9.5 \%$ \\
& Faculty $50.9 \%$ \\
& Master degree $24.4 \%$ \\
& PhD $1.3 \%$ \\
\hline
\end{tabular}

The survey was an inclusive type, meaning that a wide range of a sample population was included; the sample was representative and ad hoc. Based on the sample number $(\mathrm{N}=550)$, the study asked the following question: How often do you participate in public meetings in your municipality? The survey also included questions about factors that have influenced the community to be part or not of the decision-making process, the number of 
public meetings held by the local level, as well as the types of local decisionmaking mechanisms that have been used by local communities. Other applied methods are: literature review method, comparison between two target municipalities, analysis of the content, legal framework analysis method and statistics analysis method.

\section{Results and discussions}

The cooperation with the community is closely linked to the municipalities because the process is monitored by the central level of government and by the civil society as well. This cooperation between local government and the community is regulated by the Law on Local Selfgovernment, and also by the Administrative Instruction (MLGA) No. 02/2019 on the Organization, Functioning and Cooperation of the Municipalities with Villages, Settlements and Urban Quarters. The law on self-government "defines the establishment, form and manner of cooperation of the municipality with Local Councils on matters of public interest" (Administrative Instruction (MLGA) No. 02/2019, 2019).

The establishment of the above-mentioned councils significantly affects the organization of local communities. It is the responsibility of the local government to establish these councils together in cooperation with the local community, and should include a gender component and minority communities that live and operate in those municipalities, depending on their percentage. Additionally, the cooperation of the local government with the community is regulated through communication. According to Niklas Luhmann "communication is a synthesis or unity which results from three possible choices: information, message and meaning" (Luhmann, 2016). Examples of such events include public meetings, civic initiatives, local referendums, various petitions, etc.

According to data from the respective municipalities of the Pristina region, the councils are established by regulations that have been approved by the municipality, while the number of councils has changed from municipality to municipality. Thus, "the municipality of Pristina has established 43 councils and only 33 of them were functional and all council chairmen were men, the municipality of Fushe Kosova had established only four councils and were mainly dominated by men, the municipality of Obiliq, 12 councils, all of them functional, of which 11 of councils chairmen were male and only one was woman, the municipality of Drenas had established 44 councils and all were functional and all chairpersons were men, same with the municipality of Gracanica with 20 councils and all male chairmen" (ZKKP, 2019).

In the social context, these councils may be related to Parsons's theory, according to which societies contain certain interdependent structures, each of which performs certain functions for society maintenance, which de facto implies a function for each structure separately, and as such, they have their purposes, through which the basis of society is created. In fact, "structures refer 
to organizations and institutions such as health care, education, businesses and non-profit organizations or informal groups. These functions refer to their goals, mission and their role in the society. These structures form the basis of a social system" (Hustedde, 2009).

Parsons further divides society into four equal parts or groups, based on functional issues, which he named as per abbreviation AGIL (Adaptation, Goal-attainment, Integration, and Latency or pattern maintenance). He thinks that every society faces these four functions and according to him, if these parts are functional, then we have a society that is functional; otherwise, we have a non-functional society or community. In this regard, village councils, settlements councils and neighbourhood councils have clear goals and objectives, which are related to the organization and development of the community and are the voice of that community in decision-making.

In the municipalities of the Pristina region, we have seen that the way of organizing the councils has already changed. They started from scratch and it will still take time to become fully functional in order to have the functioning of organized communities. While, in the municipalities of other regions, there are self-initiated organized communities that have been established by village or neighbourhood councils and which have a role in organizing life in their settlements, work, daily activities, and promotion of volunteerism.

\section{Local decision-making mechanisms}

The mechanisms of direct democracy are an important instrument for involving citizens, the community, in decision-making and policy-making. The legislation on local self-government has guaranteed this by the law on local self-government, thus allowing the local government through such mechanisms to consider crucial issues which are a priori related to the needs of the community. The mechanisms of direct democracy, as a method used by the community to solve the problems they face, include petitions, referendum, civic initiatives, public meetings, budget meetings. In community development, participation not only means physical presence, but is also about "involving people in the decision-making process, implementing programs, development programs, and involving them in efforts to evaluate such programs." (Kuruvilla \& Sathyamurthy, 2015). The following table shows data in the case of municipalities of Pristina region, according to data coming from public media offices, about local-decision making mechanisms in the years $2017-2019$. 
Table 2: Use of mechanisms of direct democracy for years 2017/2019" (ZKKP, 2019)

\begin{tabular}{|l|c|c|c|c|c|}
$\begin{array}{c}\text { Mechanisms for } \\
\text { participation in } \\
\text { decision-making } \\
\text { 2017/2019 }\end{array}$ & $\begin{array}{c}\text { Municip } \\
\text { ality of } \\
\text { Pristina }\end{array}$ & $\begin{array}{c}\text { Municipa } \\
\text { lity of } \\
\text { Fushe } \\
\text { Kosova }\end{array}$ & $\begin{array}{c}\text { Municip } \\
\text { ality of } \\
\text { Obiliq }\end{array}$ & $\begin{array}{c}\text { Municip } \\
\text { ality of } \\
\text { Drenas }\end{array}$ & $\begin{array}{c}\text { Municip } \\
\text { ality of } \\
\text { Gracani } \\
\text { ce }\end{array}$ \\
\hline $\begin{array}{l}\text { Information } \\
\text { public consultancy }\end{array}$ & $\checkmark$ & $\checkmark$ & $\checkmark$ & $\checkmark$ & $\checkmark$ \\
\hline Petitions & $\checkmark$ & $\checkmark$ & $\mathbf{x}$ & $\mathbf{x}$ & $\checkmark$ \\
\hline Civic initiatives & $\checkmark$ & $\mathbf{x}$ & $\checkmark$ & $\mathbf{x}$ & $\mathbf{x}$ \\
\hline Referendum & $\boldsymbol{x}$ & $\mathbf{x}$ & $\mathbf{x}$ & $\mathbf{x}$ & $\mathbf{x}$ \\
\hline $\begin{array}{l}\text { Initiatives to remove } \\
\text { the mayor }\end{array}$ & $\checkmark$ & $\checkmark$ & $\checkmark$ & $\checkmark$ & $\checkmark$ \\
\hline $\begin{array}{l}\text { Consultative } \\
\text { committees }\end{array}$ & & & & & \\
\hline
\end{tabular}

Some of the mechanisms of direct democracy that deal with community participation in decision-making are applied and used by community. All five municipalities of the Pristina region use the information and public consultations. The municipalities of Pristina: Fushë Kosovë and Gracanica, during 2017, 2018 and 2019, have used the right of petition to solve issues of infrastructure, regulation of urban plans, regulation of rivers, and other issues. While Obilic and Drenas did not face such issues. Civic initiatives were present only in the municipality of Pristina and Obilic, in particular, in the case of land expropriation and the case of mines in the Hade village, municipality of Obilic, while in three other municipalities, these mechanisms were not used at all. Even so, the referendum has not yet been regulated by legislation. There has been no initiative taken in this regard. What stands out most in this table is the fact that no municipality has had any request or initiative for the removal of the mayor. Finally, we have consultative committees, in which citizens participate, which have not been used at all.

About the use of these important mechanisms for community participation in decision-making, civil society organizations, both local and international, have played an important role, making the community itself take the initiative to use such mechanisms. Perhaps Habermas is right when he says that "public participation has in fact, become an ideology in itself. Most resource management agencies (for public meetings) are mandated by law to engage in some form of public participation when drafting (public) policies or implementation actions." (Curtis \& Walter, 2005, p. 11) Although, in practice, the participation is still low and this is also confirmed when we conducted the research in the field. According to Habermas, "participants should follow basic rules such as staying on the topic and responding directly to objections and 
arguments. Habermas's argument is that (a) all relevant voices should be involved in the debate, (b) each participant is given an equal opportunity to participate in the debate, (c) each participant speaks with such honesty that they do not deceive themselves nor others, and (d) participants are free from any kind of oppression when they participate in this process. In this way, Habermas avoids issues of normative value and instead examines discussions as a set of neutral procedures and rules" (Etzioni, 2014). Although, in reality, such a thing happens very rarely, especially in the Balkan countries, where the ideas and opinions of the community are not taken into account or even when taken into account, was vaguely. Perhaps this is due to the influence of a number of factors, among them the lack of a democratic culture, given the fact that these countries are still in transition or have emerged late from the period of authoritarianism.

\section{Public meetings and local decision-making process}

Another important issue in the relationship between local government and community is the participation of the community in public meetings. Public meetings are of great importance for both the community itself and for the local government. The legislation does require the local government to hold at least two public meetings of general interest each year. It also requires the municipalities to report to a higher supervising level if this obligation is fulfilled. According to article 68 of the Law on Local Self Government: "Each municipality shall hold periodically, at least twice a year, a public meeting at which any person or organization with interest in the municipality may participate. The date and place of the meeting shall be publicized at least two weeks in advance. One of the meetings shall be held during the first six months of the year" (Law No 03/L-040 on Local Self Government, 2008). The community can hear of such meetings through public announcements via official municipal webpages, public spaces, local media, and social networks. All these ways of information at the same time are ways of public communication with the local community, so they could become part of policymaking and decision-taking. 
Cooperation between community and local governance - a comparative...

Diagram 1: Number of public meetings with citizens held in the municipalities of Pristina region" (Ministry of Local Government, 2020)

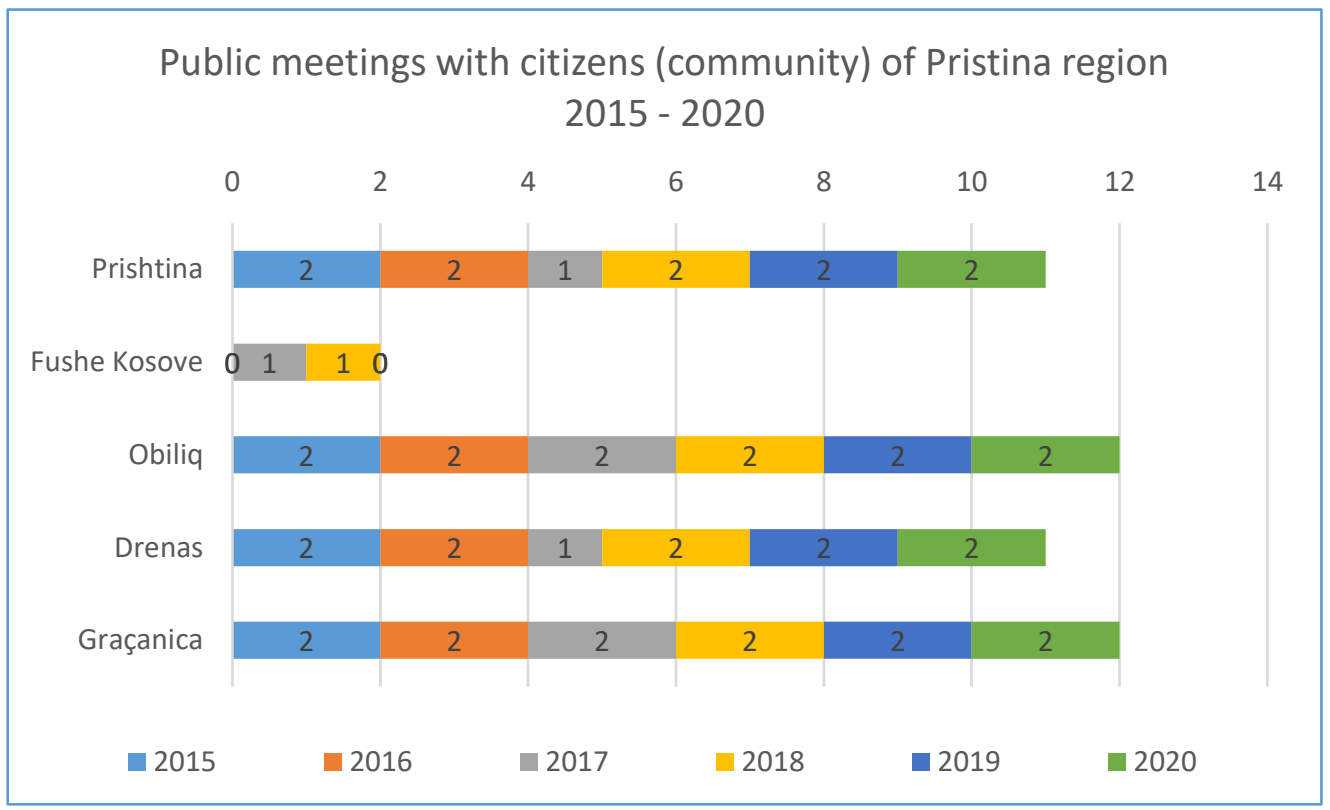

From this table, we can see the municipalities of the Pristina region, as many others have not fully respected the law on local self-government, in particular article No 68. The results show that the local self-government law was respected and applied mainly at Pristina municipality, having two meetings a year except in 2017, when only one meeting was held. The Municipality of Fushë Kosovo held public meetings in 2017 and 2018 only. From the table, we can see that municipalities of Obilic and Gracanica have abided by the law by having two public meetings in a year for given years 2015-2020. Drenas municipality held two meeting each year, except in 2017 when only one meeting was held.

Municipalities held meetings on various topics, primarily drafting regulations, regulatory plans, and issues of general public interest. But in most of the cases, this study found that the municipalities do not keep proper records on participants, either their age, gender or social status. These were the responses taken from the municipalities of the Pristina region.

Another important issue of interest for the study was the community participation, specifically the citizen's participation (community) at public meetings. The study posed this question to the citizens of given municipalities for two reasons. First, to find out about the participation of the local communities of municipalities of Pristina region at these public meetings that are linked to participation in decision-taking and policy-making. And secondly, to identify factors that affected (non) participation in such public meetings. The question was: How often do you participate in the public meetings at your 
municipality? The following table shows the results of the local communities' perceptions about participation in public meetings.

Diagram 2: Perceptions of local communities ' participation in public meetings (Kamberi, 2019).

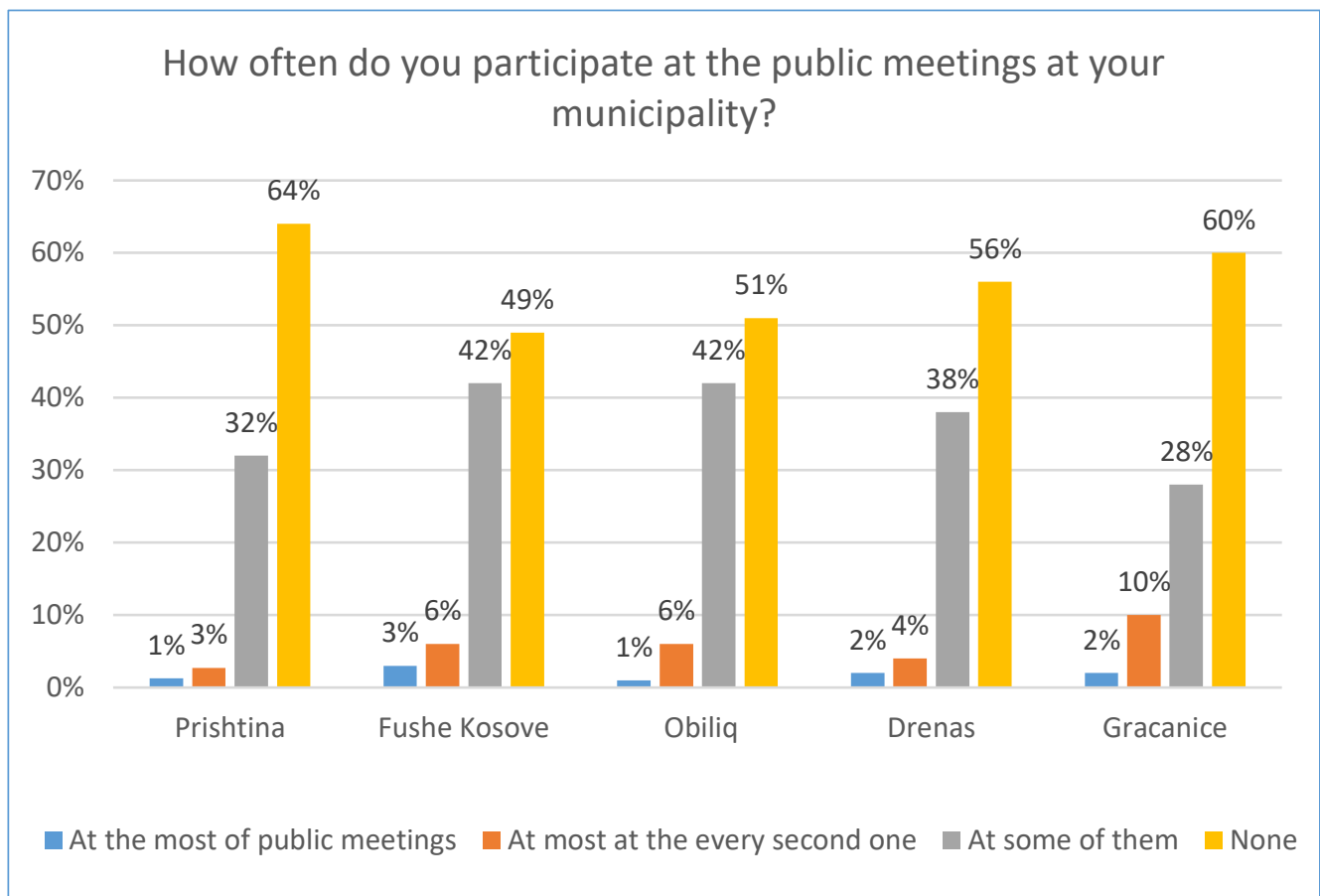

The results show the participation of local communities in public meetings. While $2.7 \%$ of them do participate in approximately half of these meetings, only $1.3 \%$ of them participate in most of the public meetings. Based on the answers from respondents from Fushe Kosove municipality, the results show that about $49 \%$ of the respondents in the municipality of Pristina answered saying that they do not participate in any of the public meetings, and $42 \%$ of them stated that they participate in some of them, while $6 \%$ of them do participate in approximately half of these meetings and only $3 \%$ of them in most of the public meetings. From the responses at the Obilic municipality, we see that about $51 \%$ of respondents state that they did not attend any of the public meetings, $42 \%$ of them did attend in some of them, and about $6 \%$ attended approximately half of them, with $1 \%$ of respondents attending most of them. Based on the answers of respondents at the municipality of Drenas, $56 \%$ of respondents stated that they did not participate in any of public meetings, and $38 \%$ attended some of them, $4 \%$ in half of them and $2 \%$ in most of the public meetings.

Results reveal that in the municipality of Gracanica about $60 \%$ of the respondents of answered that they did not participate in any of the public meetings, $28 \%$ stated in some of them, $10 \%$ in half of them, and only $2 \%$ in 
most of them. So, if we make a comparison between the municipalities in the Prishtina region, the results show that the municipality of Pristina has lower participation in public meetings compared to other municipalities.

Additionally, the study also analysed the ratio of participation of local communities in public meetings through variables of gender and education profile, from which some results have emerged, as follows:

Diagram 3: Perceptions of local community on participation in public meetings (Kamberi, 2019).

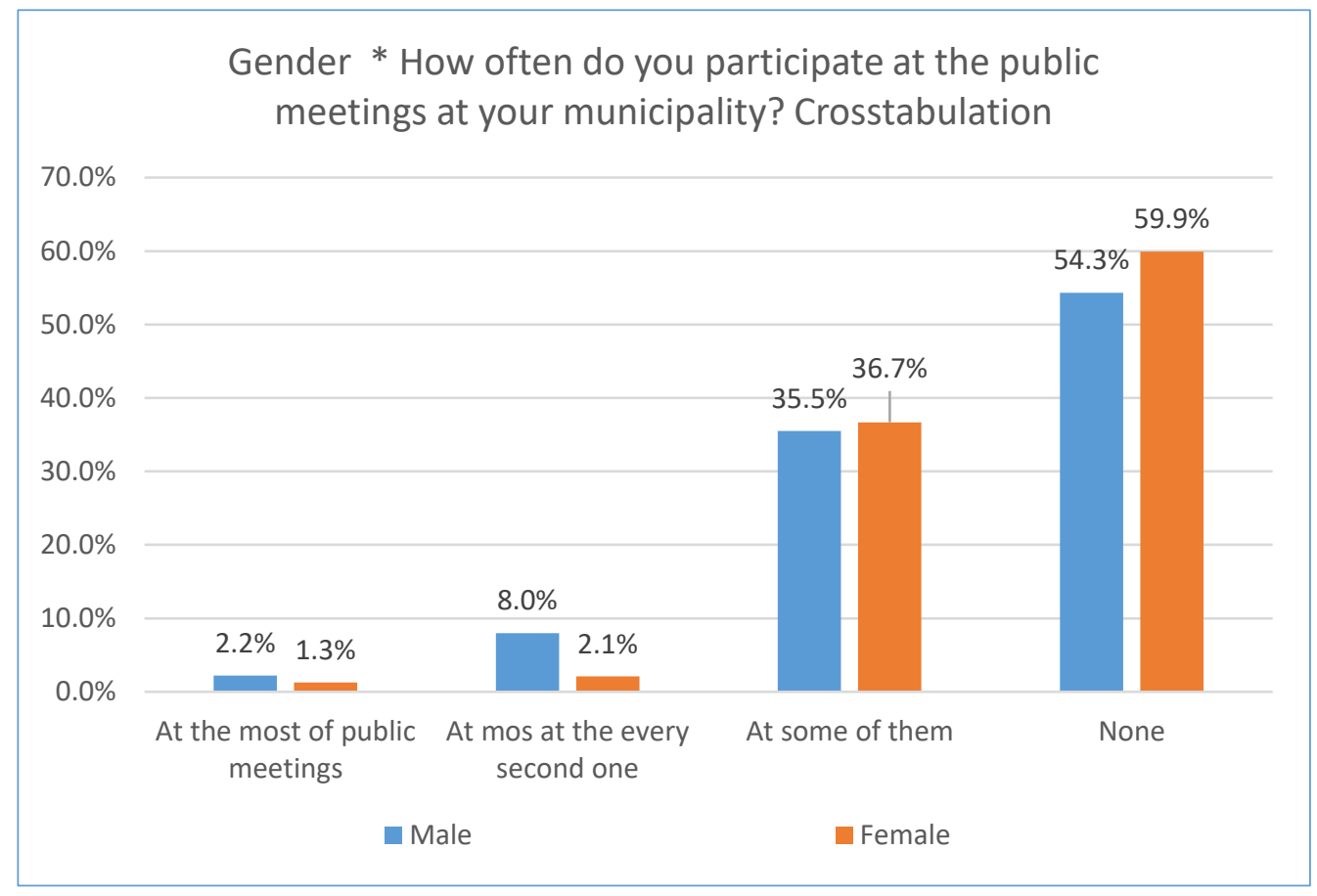

Looking at the gender perspective, regarding attendance in public meetings, we can see that $59.9 \%$ of all female and $54.3 \%$ of male respondents did not attend public meetings, and only $36.7 \%$ of female and $35.5 \%$ of male respondents attended some of the public meetings. Around $2.1 \%$ of female and $8 \%$ of male respondents confirmed that they participated almost at every second meeting while only $1.3 \%$ female and $2.2 \%$ of male respondents attended mot meetings.

From our research (Kamberi, 2019), regarding respondents education level, we found out that respondents with primary school, $57.1 \%$ of them didn't attend at any of public meetings, while $28.6 \%$ of them attended in some of these meetings, $11.1 \%$ attended almost at half of the meetings and $3.2 \%$ answered that attended in most of public meetings. In other hand, respondents with secondary level of education responded that $59.6 \%$ of them didn't attend at any of public meetings, while $28.8 \%$ of them attended in some of these meetings, $9.6 \%$ attended almost at half of the meetings and $1.9 \%$ answered that attended 
in most of public meetings. And respondents with college degree, responded that $56.16 \%$ of them didn't attend at any of public meetings, while $36.1 \%$ of them attended in some of these meetings, 5.7\% attended almost at half of the meetings and $12.1 \%$ answered that attended in most of these public meetings and the last but not the least, respondents with master and $\mathrm{PhD}$ degree education responded that $53.7 \%$ of them didn't attend at any of public meetings, while $44.8 \%$ of them attended in some of these meetings, $0.7 \%$ attended almost at half of the meetings and $0.7 \%$ answered saying that attended in most of these public meetings" (Kamberi, 2019). Similar results are also seen in the municipalities of other regions when compared to the research conducted by GAP Institute in 2018. The municipality of Kamenica was asked the following question: Have you attended any of public meetings/discussion organized by your municipality? The results show that " $86 \%$ e of citizens have declared that they did not attend any of meetings organized by their municipality" (GAP Institute, 2018). In another municipality, the Obilic, on the same question " $77 \%$ of citizens have declared that they did not attend any of meetings organized by their municipality" (GAP Institute, 2018).

This study shows that there are several factors that have influenced public participation. The results show that the citizens at the municipality level are dissatisfied with the many problems and challenges that they often face. Also, they are displeased because they feel that their opinions are not taken into consideration, thus feeling unmotivated, not respected, and as if they do not matter. This level of dissatisfaction has resulted in the community members refusing to participate in public meetings, resulting in low participation levels overall.

Additionally, there are other factors that have caused low level of attendance in the municipalities of Pristina region such as: long distances that citizens have to travel to attend, not available public transportation especially for citizens to attend on these meetings, lack of information or announcements about meeting time and place, lack of desire to attend, prejudices and stereotypes that their opinions will not be taken into consideration, lack of topics discussed in meetings that focus on community interests, such as access to local services, budget, or social welfare.

Considering the gender perspective, the results show that men answered as follows: $2.2 \%$ of them indicated that their opinions have been taken into consideration, $19.5 \%$ of them answered that their opinions are taken somewhat into consideration, $36.4 \%$ said their opinions were taken in consideration a little and $30.4 \%$ said they felt their opinions were not at all taken into consideration and $11.5 \%$ said they did not know. While female respondents answered thus: $2.5 \%$ of them answered that their opinions have been taken into consideration, $12.7 \%$ of them answered that their opinions are taken somewhat into consideration, $27.8 \%$ said their opinions were taken into consideration a little and $34.6 \%$ said their opinions were not at all taken into consideration and $22.4 \%$ said they did not know. (Kamberi, F, 2019). Therefore, in general, we can conclude that the cooperation between local government and community is not satisfactory due to the fact that local government is failing to inform the 
community and its citizens on time. Furthermore, the community members do not attend public meetings for many reasons, including that they think their opinions are not being taken into consideration or are not treated seriously.

\section{Conclusion}

The study concludes that local government in Western Balkans countries, including Kosovo, in the last decades have developed quite a number of reforms in their system; these reforms started from the year 1999. Local communities in the municipalities of those countries are in the early stages of development and organization, and they face significant challenges and problems. Although the legislation has specified the regulation of village councils, settlements and urban neighbourhoods through which local communities are organized, the lack of community organization has caused low participation in the decision-making processes of local government and not giving their contribution to a satisfactory level.

From research conducted in the municipalities of Pristina region, the results show that over $50 \%$ of local community members do not attend important public meetings. While in terms of gender profile, about $59.9 \%$ of women and $54.3 \%$ of men did not participate in public meetings. In terms of education profile, the results show that about $56.1 \%$ of the local community members with college degree did not participate at any of the meetings, whereas community members with master and $\mathrm{PhD}$ degree, about $53.7 \%$ of them did not participate in any meeting, while $44.8 \%$ of them did participate in some of these meetings. These results strongly suggest that local communities are not participating in public meetings, thus missing out in one of the main ways of cooperation between citizens and local government. Non-civic participation is a bad signal for democracy in general, as well as for the community, and society itself.

Some of the reasons why local communities do not attend these meetings include long distances required to travel to attend public meetings, lack of transportation, lack of information, prejudices and stereotypes (generalization) that their opinions will not be taken into consideration because in other municipalities such opinions have not been taken into consideration, these factors made the community to neglect and not participate in such meetings. The study shows that about $36.4 \%$ of males claim that their opinions are taken into consideration and $30.4 \%$ of them claim that their opinions are taken slightly into consideration. While $27.8 \%$ of female respondents claim that their opinions are taken into consideration and $34.6 \%$ of them claim that their opinions are taken slightly into consideration. The other factors that impact non-participation is related to the lack of topics in the public meetings which arouse interest in the community, such as access to local services, budget, or social welfare.

Local government in the municipalities of Pristina region oftentimes have not fulfilled its legal obligations, as stated in Article 68 of the Law on Local Self-Government. The requirement to hold public meetings with the 
citizens a minimum of two times a year is not always upheld. This requirement is a recommendation to local governments that comes from a higher regulatory body. However, other meetings with citizens are held on municipal topics such as infrastructure regulation and the provision of public services.

Furthermore, local decision-making mechanisms are not used fully. The study shows that from 2017 to 2019 , only some of these mechanisms have been used, such as information and public consultation, petitions, civic initiatives, and cooperation with Consultative Committees, but not any single initiative was organized to remove a mayor. Therefore, in general, the study revealed that the cooperation between local communities and local government in the municipalities of the Pristina region needs to be improved. This requires not only the commitment of local government but also the commitment of the community, civil society, and other actors who can contribute. Civic engagement can take place through small meetings, through so-called world coffee methods, face to face meetings, or communication through social networks. Such cooperation can strengthen community participation in the civil and political processes, develop the overall democratic mood, and create an active society in policy-making and decision-making processes from which both the community and the government can benefit. Therefore, it is very important that the local government possess a strategy how to involve the community in policy and decision-making process, by enriching the democracy and developing the community by giving the common contribution the commonwealth.

\section{References}

Administrative Instruction (MLGA) No. 02/2019. On the Organization, Functioning and Cooperation of the Municipalities with Villages, Settlements and Urban Quarters, https://gzk.rks-gov.net. (last acces: January 29, 2021), Retrived from: https://gzk.rksgov.net/ActDetail.aspx?ActID=21224

Baliqi, B. (2017). (Politikat Publike) Public Policy (First ed.). Prishtinë: Fondacioni-Konrad-Adenauer në Republikën e Kosovës.

Curtis, V. and Walter K. (2005). Critical Theory and the Role of Citizen Involvement in Environmental Decision Making: A Re-examination. International Journal of Organization Theory and Behavior, Vol 8(Issue 4), 11. doi:https://doi.org/10.1108/IJOTB-08-04-2005-B004

ELoGe. (2008). 12 Principles of Good Democratic Governance. Brussels: Council of Europe. (last acces: January 30, 2021), Retrieved from: https://rm.coe.int/12-principles-brochure-final/1680741931

Etzioni, A. (2014). Communitarianism revisited. Journal of Political Ideologies, $\quad$ Vol 19(Issue 241-260.

Doi:http://dx.doi.org/10.1080/13569317.2014.951142 
Council of Europe. (2013). European Charter of Local Self-Government (last acces: January 28, 2021), Retrieved from: https://rm.coe.int/europeancharter-for-local-self-government-english-version-pdf-a6-59$\mathrm{p} / 16807198 \mathrm{a} 3$

GAP Institute. (2018). The gap between the institutions and citizens in the Municipality of Kamenica. Prishtina: GAP Institute. Retrieved from: https://www.institutigap.org/documents/45763_municipality_kamenic a(en).pdf

GAP Institute. (2018). The gap between the institutions and citizens in the Municipality of Obiliq. Prishtina: GAP Institute. Retrieved from: https://www.institutigap.org/documents/90965_RAPORTI\%20P\%C3 \%8BR\%20OBILIQIN\%20(1).pdf

Hustedde, J. R. (2009). Seven Theories for seven community developers - A framework for community and economic development - An Introduction to Community Development", (Part I), In E. b. Pittman, An Introduction to Community Development (First Edition ed., p. 23). New York: Routledge. Retrieved from: https://loomiouploads.s3.amazonaws.com/uploads/a857276f9762676b869e7112c39 6824c/An\%20Introduction\%20to\%20Community\%20Development.p df

Iain Mc Lean. (2001). (Fjalor Politik $i$ Oxfordit) The Concise Oxford Dictionary of Politics Tiranë: Shtëpia e Librit \& Komunikimit.

Kamberi, F. (2019). Community Development and Local Governance Comparative Study of Municipalities of the Pristina region: results of pilot Project of PhD. Dissertation. Univerity of Prishtina "Hasan Prishtina", Sociology. Prishtina: Phd theises.

Kamberi, F. (2019). (Dilemat e Tranzicionit) Dilemas of Transition (First Edition ed.). Prishtina: Artini.

Kamberi, F. \& Baliqi, B. (2018). Participation of the Community in the Decision-Making Process - Case the Municipality of Pristina. (A. Kataeve, Ed.) Path of Science, Vol 4(No 8), 5004. DOI: 10.22178/pos.37-9

Kukovič, S. (2015). New Forms of Participatory Democracy at Local Level: eCitinzen?, Journal of Comparative Politics, 8, 2015, 2, 27-35, ISSN 1338-1385.

Kuruvilla, Ch. \& Sathyamurthy. K. (2015). Community Participation towards effective social work practice. Indian Journal of Applied Research, Vol 5 (Issue 12), 16. 
Law No 03/L-040 on Local Self Government. (2008, February 20). https://gzk.rks-gov.net. (last acces: January 30, 2021), Retrieved from: https://gzk.rks-gov.net/ActDetail.aspx?ActID=2530

Luhmann, N. \& De Giorgi. R. (2016). (Teoria e Shoqërisë) Theory of Society. Tirana: Pika pa Sipërfaqe.

Ministry of Local Government. (2021). Municipal Functioning Report 20152020. Prishtina: MLG. Retrieved from: https://mapl.rksgov.net/en/mlga-annual-reports/

Pollozhani, B. \& Dobjani, E. \& Stavileci, E. \& Salihu, Lazim. (2010). (E drejta Administrative - Aspekte krahasuese) The Administrative right Comparative Aspects (First Edition ed.). Tetovë - Maqedoni: Asdreni.

R. Phillips and Robert H. Pittman. (2009). An Introduction to Community Development (First Edition ed.). New York, USA: Routledge.

Siisiäinen, M. (2000). Two Concepts of Social Capital: Bourdieu vs. Putnam . Dublin: Paper presented at ISTR Fourth International Conference. (last acces: January 29, 2021), Retrieved from: https://www.researchgate.net/publication/200031251_Two_Concepts _of_Social_Capital_Bourdieu_vs_Putnam

Wilson, R. H. (2000). Understanding local governance: an international perspective. Revista de Administração de Empresas, Vol 40 (No 2), 58. DOI: $10.1590 /$ S0034-75902000000200006.

ZKKP. (2019, December 02-10). (Mekanizmat lokal të vendimmarrjes). Local Mechanism of Decision making) (F. Kamberi, Interviewer) Prishtina, Fushe Kosove, Obilic, Drenas, Gracanice. 